\title{
Diagnosing the Organizational Culture of Rural Community Banks in Ghana and Its Effects on Their Financial Performance
}

\author{
Jenkins A. Asaah (Correspondence) \\ Kumasi Technical University, Kumasi, Ghana \\ Beatrice L. Asaah \\ Kumasi Technical University, Kumasi, Ghana \\ Austin W. Luguterah \\ Kumasi Technical University, Kumasi, Ghana
}

Received: November 12, 2019 Accepted: May 30, 2020 Published: June 17, 2020

doi: 10.5296/jsss.v7i2.15085 URL: https://doi.org/10.5296/jsss.v7i2.15085

\begin{abstract}
Rural Community Banks (RCBs) are important rural development partners in Ghana. They are the lifeline of credit to small businesses and individuals who do not have the necessary collateral and capacity to borrow from the traditional commercial banks. However, the RCBs are confronted with increasing customers' demands, keen competition, and poor financial performance which has led to $26 \%$ of the country's RCBs earmarked for liquidation. This is a serious threat to the sustainability of the country's RCBs prompting serious concern among stakeholders of rural banking. Previous studies have looked at the issue from the perspective of regulations, corporate governance, and ownership structure. This paper seeks to look at the problem from the organizational culture and product innovation point of views.

Based on the Competing Values Framework and empirical studies, hypotheses were stated and tested using data collected from 92 RCBs. The data were analyzed using the Smart PLS of SEM.

The findings are that RCBs in Ghana exhibit four different cultural types but the dominant culture is control-oriented. Product innovation has a strong impact on financial performance.
\end{abstract}


Cultural orientations such as compete-oriented and innovate-oriented can support RCBs to introduce innovative financial products (product innovation) while control-oriented cannot.

Based on the findings, the RCBs are encouraged to create a Research and Product Development (RPD) unit. This unit should develop a cultural orientation that values and encourages freedom of thought, and experimentation of innovative ideas. The bank as an institution should value customer and competitor interactions which serve as a feedback platform for the development of innovative financial products and services.

The theoretical contribution of this paper is that organizational cultural orientations that value and focus on customer satisfaction, and interaction with competitors nurture product innovation.

Keywords: Organizational culture, Product innovation, Financial performance, RCBs, Ghana

\section{Introduction}

It is a fact that rural communities lack so many amenities as compared to urban centers. In Ghana, governments and non-governmental organizations (NGOs) over the years had sought to improve economic activities in these areas by the provision of social and economic projects capable of enhancing the economic life of rural folks. One of such projects is the establishment of Rural Community Banks (RCBs). The term Rural Community Banks (RCBs) is also referred to as Community Banks or Rural Banks in some parts of the world.

Rural Community Banks (RCBs) are major players in the banking sector of Ghana. They were introduced as a means of closing the gap, in terms of the provision of financial services, between the urban centers and the rural areas (Bank of Ghana, 1995; Nair \& Fissha, 2010). RCBs are commercial banks that are owned by members of a rural community through the purchase of shares(Steel and Andah, 2004). They differ from the traditional universal banks in terms of size, assets, and geographical operational areas. Their operations are confined to rural areas of the country. They are licensed and regulated by the Bank of Ghana(Bank of Ghana, 1995). In Ghana, the mandate of RCBs includes to facilitate the mobilization of rural savings; to offer credit and other banking services to rural folks and to act as an instrument for rural development (Bank of Ghana, 1995). RCBs are the main financial service providers for rural dwellers and Small and Medium Enterprises (SMEs)(Nair and Fissha, 2010) and represent almost half of the total banking outlets in Ghana (IFAD, 2008). Therefore, the importance of RCBs in the socio-economic development of Ghana cannot be overemphasized.

There are, however, some challenges confronting the RCBs in the country. These include nonperforming loans, low capitalization, low asset quality, liquidity crises, and profitability (Adusei, 2015; Bank of Ghana, 2017). Besides the above, RCBs are faced with increasing customer demand and stiff competition from other commercial banks (PricewaterhouseCoopers, 2010). Some of the universal banks, the savings and loan companies, the credit unions, microfinance institutions, and financial non-governmental organizations have expanded their activities into the rural areas targeting the customers of RCBs as well as their staff thereby competing with the RCBs in the rural financial market. This has resulted in the poor financial performance of some of the RCBs. In recent times, about $26 \%$ of the RCBs are at risk of closure due to poor financial performance (Bank of 
Ghana, 2017), creating serious concern among stakeholders of RCBs.

To overcome the keen competition and improve their financial performance (profit) extant literature has recommended commercial entities to embrace innovation (Amabile \& Pratt, 2016; Chang \& Lee, 2007; Zhou \& Shalley, 2008; Gumusluoglu \& Ilsev, 2009; Tellis et al., 2009; Varis \& Littunen, 2010). Innovation refers to 'the introduction of new services, new products, or the use of new technology, administrative systems or new organizational structures with the sole aim of improving the performance of the organization' (Tian et al., 2018). According to OECD Oslo Manual (2005), there are three levels of innovation novelty namely new to the firm, new to the market, and new to the world. In this paper, the focus is on product/service innovation. In the context of the Ghanaian banks, we define service/product innovation as the adoption and or the introduction of technology-based financial products and customized financial services. In Ghana, product innovation mostly takes place in the form of adoption and adaption of existing products/services to meet local needs (Atuahene-Gima \& Ko, 2001). Financial products such as electronic banking, SMS alert, mobile banking, ATMs, among others enables banks to extend their services to other markets at a modest operating cost (Berger \& Nakata, 2013; Boor et al., 2014). Also, these innovative financial products and services serve as sources of revenue to the banks because they attract potential customers (Nooteboom, 1994; Woodcock et al., 2000; Zhou, 2006). The unique environment in which these RCBs operate calls for the provision of unique and customized financial products and services that meet the unfilled needs of rural folks. The wide access to telecommunication by rural folks of Ghana and the significant increase in mobile phone users (Dasmani, 2016) serve as a great opportunity for RCBs to take advantage of and introduce low-cost innovative financial products and services via mobile phones.

The ability of the RCBs to capitalize on this opportunity and introduce innovative financial products capable of meeting the needs of rural folks, thereby attracting more customers largely depends on several factors which include the cultural orientation of the bank (Lyons et al., 2007). Research has shown that the cultural orientation of a commercial entity can either aid or impede its effort to be innovative (Naranjo-Valencia et al., 2010; Tesluk et al., 1997). This is so because organizational culture influences the work attitudes and behavior of members of the organization (Hemmelgarn et al., 2006). However, the organizational culture is often overlooked when decision-makers of commercial entities embark on re-engineering activities.

Past studies (Boadi et al., 2016; Godfred, 2013, 2015; Castellini \& Agyemang, 2012; Nyarko et al., 2017) have delved into the poor financial performance of the country's banks from the perspective of regulations, corporate governance, ownership structure, and organizational structure. This study seeks to look at the problem from the organizational culture and innovation point of views. Extant literature strongly recommends that for commercial entities to survive in the business environment which is characterized by keen competition, they need to be innovative (Im \& Rai, 2008; Chang \& Lee, 2007; Zhou \& Shalley, 2008) and one crucial factor which influences innovative behavior in the workplace is organizational culture (Lyons et al., 2007; Rohlfer \& Zhang, 2016; Tian et al., 2018).

In view of the fact that RCBs in Ghana are major socio-economic players in the development of rural areas of the country, the paper seeks to identify the single-dominant organizational 
culture prevailing within RCBs and further explores the impact of each of these identified organizational cultural orientations on the financial performance of the banks through product innovation.

To achieve the above-mentioned objectives, we review the literature on organizational culture and then develop hypotheses based on the competing values framework and empirical studies. The methodology, the results, discussion, and conclusion sections follow in that order.

\section{Theoretical Framework and Hypotheses Development}

The paper explores the interaction between types of organizational culture and product innovation and its resultant effect on financial performance. Figure 2 shows the conceptual framework of the study. What is the single-dominant organizational culture prevailing within the RCBs in Ghana and to what extent do these identified cultures affect their efforts to introduce innovative financial products and services to promote the growth and development of the Ghanaian rural economy? The paper seeks to answer these research questions.

\subsection{Organizational Culture (OC)}

From the extant literature, there are several definitions of organizational culture, though there is a thin line of difference between them. Some scholars have tried to make the definition of OC as simple as possible, while other proponents think otherwise by making the definition broader and deeper. For instance, Lundy \& Cowling (1996) define OC as the way we do things around here. This definition is simple and explains organizational culture as the way members of an organization carry out their work. On the other hand, Poskiene (2006) defines OC as the complex set of ideologies, traditions, commitments, and values that are shared throughout the organization, and that influences how the organization conducts its whole performance becoming a potential source of innovation, advance, and advantage. Thakor (2016), defines OC is the collective assumptions, expectations, and values that reflect the explicit and implicit rules determining how people think and behave within the organization. In the opinion of Asaah et al. (2019), OC is the assumptions, norms, values that have emerged and developed over time and serve as interpretive frameworks that guide and influence the behavior of members of an organization.

The various definitions of organizational culture are complementary to one another. Based on the various definitions of organizational culture, the following characteristics can be derived. Organizational culture is a framework that enables members of an organization to understand and interpret organizational phenomena. It is shared. OC consists of norms, values, assumptions, and therefore can be described as being intangible. Also, OC is created and sustained as a result of the interaction of members of an organization. Lastly, OC emerges and develops over time. In terms of functions, OC influences behavior and work attitudes (Hemmelgarn et al., 2006; Jarnagin \& Slocum, 2007); it helps in the harmonization of organizational capabilities (Day, 1994; Ito et al., 2012); it can thwart or facilitate organizational efforts in reaching its goals ( Denison 1990; Lundy \& Cowling 1996; Tesluk et al., 1997) and lastly due to its intrinsic nature which is difficult to copy by competitors, it serves as a source of sustained competitive advantage (Hofstede, G. \& Hofstede, 2005; Ogbonna \& Harris, 2000). 


\subsection{Types of Organizational Culture}

There is a divided opinion among scholars of organizational behavior on the various types of organizational culture. Wallach (1983) postulates three main types of organizational culture

Namely: supportive, bureaucratic, and innovative. Quinn and Spreitfzer (1991) added their voice by conceptualizing organizational culture into a rational culture, hierarchical culture, group culture, and development culture. In contrast, Martin (1992) viewed organizational culture from three perspectives (i.e. Integration, fragmentation, and differentiation). In a related development, Goffee and Jones (1998) identified four forms of organizational cultures (i.e. communal networked, fragmented, and mercenary). Cameron and Quinn (1999, 2006) also identified four types namely, market, adhocracy, hierarchy, and clan. It's worth mentioning that there are other typologies of organizational culture developed by other researchers such as Harrison (1972), Schein (1985), Denison and Mishra (1995), Sonnenfeld (1988).

The competing values framework (CVF) developed by Cameron and Quinn $(1999,2006)$ is the one mostly used in the study of organizational culture of institutions (Asaah et al., 2020; Dadzie et al., 2012; Naranjo-Valencia et al., 2016; Schneider et al., 2013). Therefore, this research uses this model to operationalize organizational culture.Cameron \& Quinn (1999, 2006) postulated four cultural types. These are clan, hierarchy, adhocracy, and market. These cultural types have different characteristics. The CVF can be simplified as collaborate-oriented, compete-oriented, control-oriented, and innovate-oriented cultures (see Figure 1).

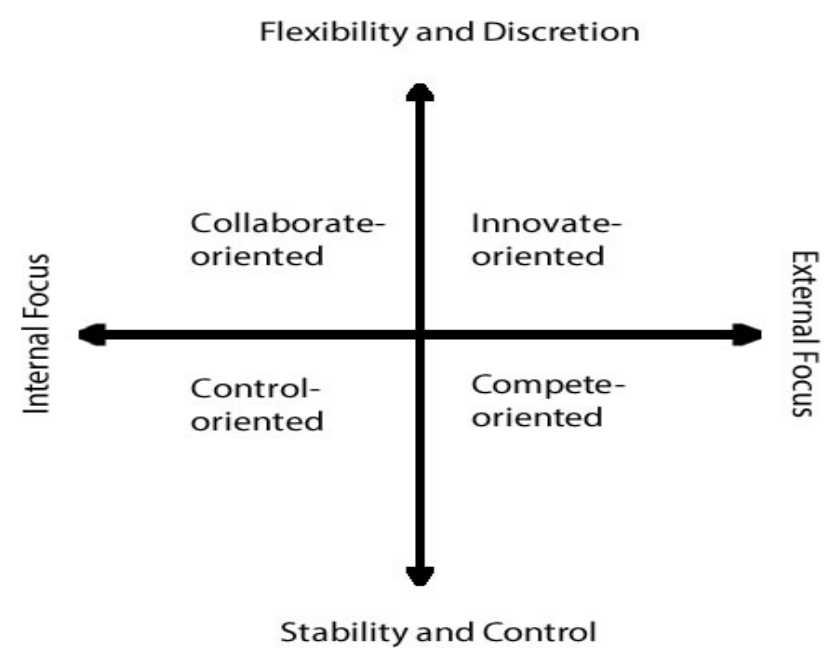

Figure 1. The Competing Values Framework by Cameron and Quinn $(1999,2006)$

Cameron and Quinn (1999, 2006) Competing Values Framework presents a pictorial situation within an organization on how various values cherished by members of an organization compete among themselves for attention and tend to influence as well drive members of the organization to tow a particular line of action. The framework has four quadrants. Collaborate-oriented culture (clan) whose core values include employee development, 
consensus building, and teamwork among staff. The control-oriented culture (hierarchy) cherish adherence to rules and regulations, hierarchical structures, and control mechanisms aimed at reducing risks while improving internal efficiency. These two cultural orientations are referred to as internally focused cultures. They focus on the internal environment of the organization. The hallmark of innovate-oriented culture (adhocracy) includes organic organizational structures, flexibility, freedom of thought, and experimentation of new innovative ideas. Dominating the industry with innovative products is their ultimate goal. The core values of a compete-oriented culture (market) include corporate competitiveness, customer satisfaction, and outpacing competitors. Its ultimate goal is to achieve a lion share of the market within the shortest possible time. Both compete-oriented and innovate-oriented focus on the external environment of the organization.

The paper used this framework to operationalize organizational culture in the RCBs. The choice of this model over others is because it is the most widely used model in measuring organizational culture (Asaah et al., 2019; Dadzie et al., 2012; Naranjo-Valencia et al., 2016; Schneider et al., 2013). This is because it has incorporated the viewpoints of other researchers and boast of few criticisms.

\subsection{The Nature of the Organizational Culture (OC) Prevailing Within the Rural Community Banks in Ghana}

According to the literature, the OC of banks varies from a geographical location to another. In a review of some banks in the U.S.A, Thakor (2016) indicated that the dominant culture prevailing in these banks is clan culture. In India, it is also a clan culture (Mehta \& Sharma, 2016). In Netherland, Marcella (2010) surveyed the OC of financial institutions in that country and it is market, however, the employees preferred an adhocracy culture. In Albania, Leskaj et al. (2013) identified four main types of OC but the dominant culture is market.

The literature is scanty of the OC of banks in Africa. In Kenya, it is market culture (Mwashighadi \& Kising'u, 2017) while in South Africa, it is adhocracy culture (Davidson \& Coetzee, 2007). In Ghana, according to Mariama-Zakari and Owusu-Ansah (2013), it is market culture. The activities of banks include receiving monies from depositors and keeping them safe for them, giving of loans to both individuals and corporate bodies, and lastly, making prudent investments that will yield higher returns. The monies belong to the depositors and banks ensure that appropriate measures are put in place to protect the depositors' monies. To succeed in doing this effectively and efficiently calls for risk management, compliance, and controls (Doyle et al., 2013). As much as possible banks try to avoid or reduce risk in all their activities. Managers and regulators of banks try to implant effective risk management in the bank's operations. Taken into consideration the peculiar nature of the banking industry in Ghana, where proper identification and address system are a major challenge, it is expected that RCBs in Ghana will operate in a control-oriented environment. Therefore, we hypothesized that:

H1: The RCBs in Ghana will exhibit all the four types of organizational culture but the dominant one will be control-oriented culture. 


\subsection{Organizational Culture and Product Innovation}

RCBs are regulated by the government through the central bank to protect the interest of the public. These regulations are aimed at reducing risks and improving efficiency and financial soundness. Though the RCBs are regulated, the corporate culture at the institutional level is not significantly influenced by such regulations (Fiordelisi et al., 2015).

In general terms, product innovation is the introduction of new goods or services to the market (OECD Oslo Manual, 2005). In the opinion of Susman \& Min (2006), it is the introduction of new functions or additional features into an existing product/service. According to the diffusion theory by Rogers (2003) adopting a product/service that is being practiced elsewhere but perceived as new to the firm adopting it, is also regarded as an innovation. In this paper, we define service/product innovation as the adoption and or the introduction of technology-based financial products and customized financial services.

Over the years, the banking industry has witnessed the introduction of several innovative financial products. The sector has taken advantage of the opportunities created by Information and Communication Technologies (ICT) to introduce novel financial products. Through innovative products such as ATMs, e-payment, SMS alert, internet banking, mobile banking, and others, banks can reduce transaction costs while extending their products and services to other markets without necessarily the physical presence of the bank (Littler \& Melanthiou, 2006). Banks in developing economies are expected to adopt these innovative products and further introduce other innovative products and services to meet local needs. The comfort and the convenience that these products offer to users tend to attract customers and potential customers thereby serving as avenues for the banks to make a profit (Franklin et al., 2014). Customers of banks are varied and have different needs which calls for customer segmentation and designing appropriate and tailored made innovative products and services to meet their needs.

The ability of a bank to do this is influenced by several factors including the organizational cultural orientation of the bank (Lyons et al., 2007). Theoretically, Martins \& Terblanche (2003) argue that institutions with a cultural orientation that values organic structures and flexibility (adhocracy culture) will favor innovativeness. Empirical studies on how the culture of an organization can impact on its ability to introduce innovative products and services have produced mixed results.

In the empirical studies by Naranjo-Valencia et al. (2016), it was found out that clan culture has no significant effect on product innovation. Other studies show otherwise (Mclean, 2005; Jamrog et al., 2006). Clan culture is an internally focused culture with some amount of flexibility. In a typical organizational system, this kind of culture enhances open communication, teamwork among employees, and collaboration between various divisions of the organization(Cameron and Quinn, 2006). This facilitates the flow and sharing of information, knowledge, and ideas that aid product, process, organizational and marketing innovations (Amabile and Pratt, 2016). Open communication and flexible nature encourage employees to think creatively to provide solutions to the challenges of the institution. Some scholars argue that a team of a diversity of talented interdisciplinary members promotes creativity and innovation (Mclean, 2005; Casta neda, 2015). In a study by Llorens et al. (2015), it was found out that the cohesion of teams supports product innovation. In the 
opinion of Hartnell et al. (2011), the participatory, employee involvement, teamwork, and open communication characteristics of clan culture foster product innovation. Hurley (1995) found out that the more the culture emphasizes people and career development, the higher the group/team's innovativeness will be, and the more the culture emphasizes participation and open decision making, the higher the innovativeness will be. In view of the above, it is predicted that:

H2: Collaborate-oriented (clan) culture supports product innovation.

Per the Competing Values Framework, the adhocracy culture is an externally focused culture that articulates values such as flexibility, freedom of thought, creativity, risk-taking, and entrepreneurial skills (Cameron and Quinn, 2006). These values encourage employees to take risks and utilize creativity to identify and respond to unique customer needs (Cameron and Quinn, 2006). Theoretically, Martins \& Terblanche (2003) argue that institutions with a cultural orientation that values organic structures and flexibility (adhocracy culture) will favor product innovation. Most empirical studies confirm this assertion (Ruvio et al. 2014; Liao et al., 2015; Naranjo-Valencia et al., 2010; Naranjo-Valencia et al., 2016). Tian et al. (2018) are of the view that the characteristics of adhocracy culture are supportive of firms to adapt to a new environment and bring critical resources together to engage in innovative and creative ventures. Studies by Dayan et al. (2016) and Brettel et al. (2015) found out that organizations with adhocracy culture are more responsive to new product development. In the opinion of Laforet (2016), the externally focused nature of adhocracy culture serves as a strong and significant antecedent of entrepreneurship which exposes an organization and its employees to diverse sources of knowledge, improving its ability to identify opportunities for new product development. Hartnell et al. (2011) argue that an externally focused culture such as adhocracy culture enables employees to readily identify new market segments and unfulfilled customer needs through environmental scanning which fosters a strategic thrust of creating new products, services, niches and processes. According to Gilson et al.(2005), adhocracy culture induces employees to produce novel, adhoc solutions to improve product and service quality. In view of the above, it is hypothesized that:

H3: Innovate-oriented (adhocracy) culture facilitates product innovation.

Empirical studies on the effects of market culture on the ability of an organization to come out with innovative products and services have produced mixed results. Per the Competing Values Framework, the market culture is an externally focused culture which emphasizes on competitiveness, goal achievement, customer satisfaction, and environment exchange. The findings of Jaskyte \& Dressler (2005), and Jaskyte \& Kisieliene (2006) indicate that stable and control-oriented culture (hierarchy and market cultures) do not support product innovation. A study by Ogbeibu et al. (2018) also found out that market culture does not support product innovations. In a study of SMEs in China by Naidoo (2010), it was found that market culture has a negative effect on innovation. Other scholars such as Christensen and Bower (1996), Voss and Voss (2000) are of the view that market culture may lead to product imitation rather than innovation. The results of a recent study on the effect of market culture on product innovation by Naranjo-Valencia et al. (2016) were inconclusive. Contrary to the above findings, Kim et al. (2004) and Zhou et al. (2005) found a positive link between 
market culture and product innovations. In a related development, Laforet (2009) found out that market culture has a positive association with innovation. Similar findings were found by Salavou and Avlonitis (2008). Market culture facilitates a strategic focus of competing and achieving by incorporating customers' feedback and leveraging existing resources to deliver new quality products and services at a competitive price(Cameron and Quinn, 2006). Cameron et al. (2006) argue that market culture maintains an external focus on customers and competitors to garner the competitive foresight needed to anticipate customers' evolving needs, standards, and expectations which enable an organization to deliver desirable new products and services. According to Atuahene-Gima and Ko (2001) market culture is positively associated with product innovation because such culture understands, monitors, and responds to the needs of customers. Empirical studies by Salavou et al. (2004), and further confirm that market culture enhances the innovative performance of an organization. In the light of the above evidence, it is predicted that:

H4: Compete-oriented (market) culture supports product innovation.

Concerning the effect of hierarchy culture, Naranjo-Valencia et al. $(2010,2016)$ found it to have a negative influence on product innovation. They argue that hierarchy culture emphasizes hierarchical structures and control mechanisms while the key innovation values such as creativity, freedom of thought, risk-taking attitudes are missing. According to Amabile (1998), and Amabile \& Pratt (2016), a controlled environment stifles creative thinking of employees and for that matter the innovativeness of an organization. In the opinion of Buschgens et al. (2013), and Naranjo-Valencia et al. (2010), hierarchy culture reduces external idea stimulation, information gathering, organizational learning and thus be detrimental to innovation. Laforet (2016) argues that hierarchy culture emphasis on conformity to rules and procedures, hierarchical organizational structures, and centralized decision-making process keeps it external environment at a distance making such cultural orientation less adaptable and accommodative to change. Jaskyte \& Dressler (2005), and Jaskyte \& Kisieliene (2006) also concluded that control-oriented culture (hierarchy culture) does not support product innovation. In the investigation of Ogbeibu et al., (2018), it was found out that hierarchy culture has no significant effect on product innovation. In view of the above, it is hypothesized that:

H5: Control-oriented (hierarchy) culture has a negative effect on product innovation.

\subsection{Product Innovation and Financial Performance}

Product innovation is the introduction of new products or services into the market (OECD Oslo Manual, 2005). New products or services attract more customers resulting in more revenue for the organization (Susman \& Min, 2006; Franklin et al., 2014). Newly introduced products/services face limited competition affording the producer to make some economic gains but with time the profits drop due to imitation by competitors (Littler \& Melanthiou, 2006). However, commercial entities that continue to introduce innovative products and services maintain their economic gains (Sharma \& Lacey, 2004). Hence commercial entities have been encouraged to continuously innovate. According to Woodcock et al. (2000) commercial entities that often introduce new products or services perform better in the market than those that do not. Studies conducted by Saeidi et al. (2018), Lin and Chen (2007), 
Langerak and Hultink (2008) among others confirm that product innovation improves the profits and growth of firms. Therefore, it is hypothesized that:

H6: Product innovation improves financial performance.

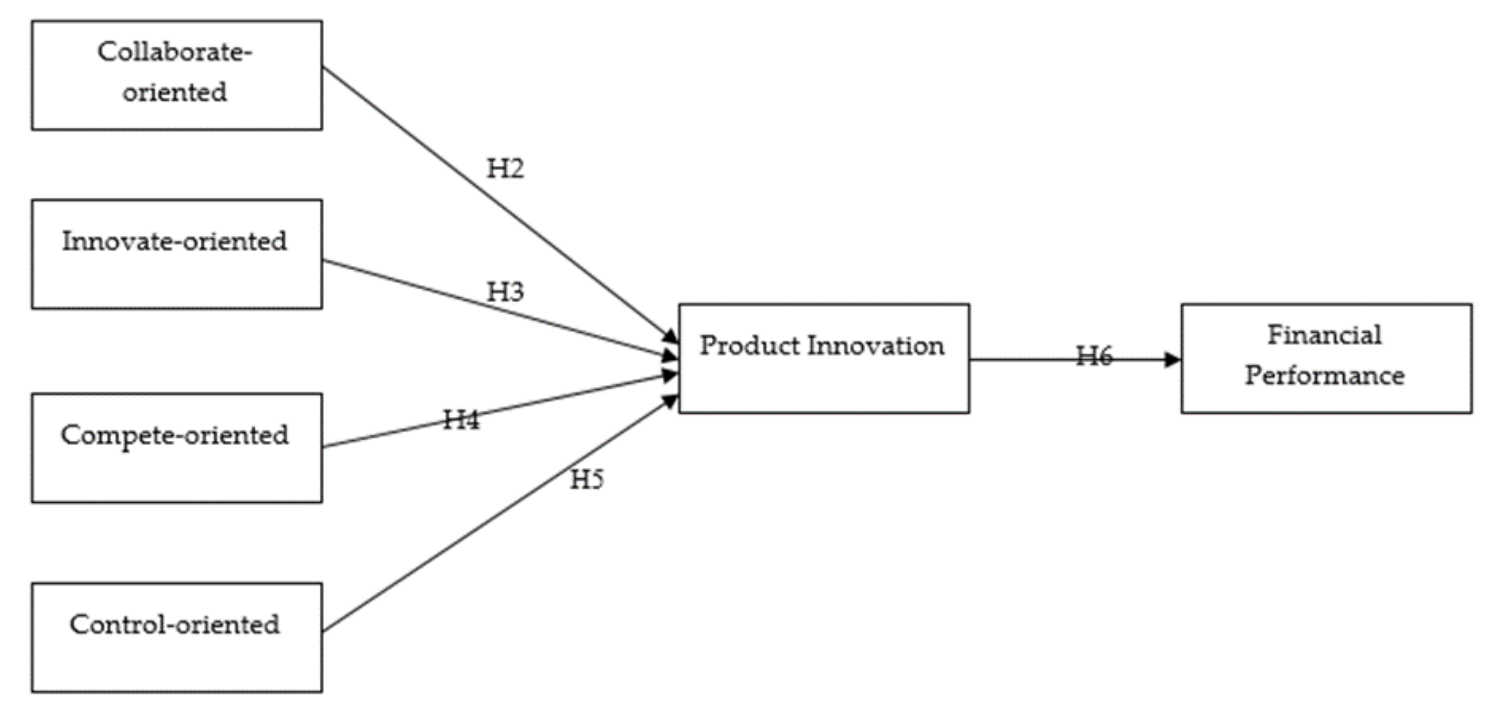

Figure 2. Conceptual framework of the paper

\section{Methodology}

\subsection{Sample and Data Collection}

The data were collected from Rural Community Banks (RCBs) in Ghana using questionnaires. RCBs were selected for the study in view of the role they play in the socio-economic development of rural communities in Ghana. Currently, $140 \mathrm{RCBs}$ are operating in the country (Bank of Ghana $[\mathrm{BoG}], 2017$ ). To be sure that respondents understand the questions, a pilot test was conducted with some of the banks which resulted in the amendment of some of the questions. The final questionnaires were distributed to the headquarters of these banks by express mail service and some in person. Attached to the questionnaire was a cover letter that explains the purpose of the survey and the assurance of the confidentiality of their responses.

Although 98 RCBs responded, 92 filled questionnaires completed by 828 staff of 92 RCBs were used for the analysis. This represents a response rate of $65.71 \%$. The banks' average age and size were 32 years $(\mathrm{SD}=8.32)$ and $99(\mathrm{SD}=57.03)$ respectively. $55 \%$ of the respondents were males. The majority $(57 \%)$ of the respondents were $1^{\text {st }}$-degree holders while $10 \%$ and $33 \%$ were $2^{\text {nd }}$-degree and HND/DBS holders respectively. In terms of their length of service, $17 \%$ of the respondents had served less than 10 years while the rest had served more than 10 years.

$\mathrm{HND}=$ Higher National Diploma; DBS $=$ Diploma in Business Studies. 


\subsection{Measures}

\subsubsection{Organizational Culture}

The Organizational Culture Assessment Instrument (OCAI) developed by Cameron was adapted to measure the organizational culture of the banks. This instrument has been widely used to measure organizational culture (Dadzie et al., 2012; Igo \& Skitmore, 2006; Lau \& Ngo, 2004; Naranjo-Valencia et al., 2010; Obenchain \& Johnson, 2004; Stock et al., 2007). The respondents ( 3 junior staff and 3 senior staff), on a 7-point Likert scale (1= Disagree strongly, $7=$ Agree strongly), were asked to appraise each of the statements that describe the prevailing situation in the bank. Sample items included 'The management style in the bank is characterized by teamwork, consensus, and participation'. 'The bank is a very controlled and structured place. Formal procedures generally govern what people do'. Using SPSS, the average score of the respondents was computed to represent the response from each bank. Table 3 shows the reliability test.

\subsubsection{Product Innovation}

The focus was on the introduction and or adoption of technology-based financial products and services. These include SMS alert, mobile banking, mobile money, electronic banking (Berger and Nakata, 2013; Boor et al., 2014). On a 7-point Likert scale (1= Disagree strongly, $7=$ Agree strongly), the General Manager/Manager, HR Officer/Manager, and the Accountant were asked to evaluate the extent to which these variables were achieved by the bank for the past three years. Sample items included 'for the last 3 years, customers of the bank can access their accounts balance, and other transactions anytime anywhere (via the internet) without the need to come to the premise of the bank; for the last 3 years, customers of the bank can receive text messages of transactions on their phones'. Using SPSS software, the average score of these officers was computed to represent the score of each bank. The reliability test of the variables is indicated in Table 3.

\subsubsection{Financial Performance}

Due to the unwillingness of some managers to share objective performance data (Boyer et al., 1997; Ward and Duray, 2000), a subjective approach was adopted in measuring the financial performance of the banks. On a 7-point Likert scale, the General Manager/Manager, HR Officer/Manager and the Accountant of each bank were asked to evaluate the financial performance of the bank for the past three years in terms of return on assets, return on investments, yearly profit, and achievement of yearly profit targets ( Collier et al., 1989; Marx et al., 1999; Steyn et al., 1998). This subjective practice is common in empirical research (Beamish \& Lupton, 2009; Henri, 2006; Hult et al., 2008). In view of the role/positions of these respondents in the banks, they are conversant with the financial performance of the bank and therefore, can give an accurate subjective evaluation of the bank's financial performance (Choi \& Eboch, 1998). Table 3 shows the reliability test. The average score of the respondents was computed using SPSS to represent the response from each firm.

\subsection{Statistical Analysis}

The study used Smart PLS (partial least squares) of Structural Equation Modeling (SEM) to analyze the data. Smart PLS of SEM was used to establish the relationship between the main 
constructs. Prior to the analysis, the data were cleaned and the descriptive statistics determined using Excel and SPSS respectively.

\section{Results}

\subsection{Descriptive Statistics}

Table 2 shows the means, standard deviations, and Pearson correlation coefficients among the variables. None of the variables are highly correlated as all the correlation coefficient magnitudes are below 0.7 .

Table 2. Mean, Standard Deviation and Correlations between Variables

\begin{tabular}{|c|c|c|c|c|c|c|c|c|c|}
\hline & Variable & Mean & $\begin{array}{l}\text { Std. } \\
\text { Deviation }\end{array}$ & 1 & 2 & 3 & 4 & 5 & 6 \\
\hline 1 & $\begin{array}{l}\text { Collaborate-oriented } \\
\text { Culture }\end{array}$ & 5.24 & 1.116 & 1 & & & & & \\
\hline 2 & $\begin{array}{l}\text { Innovate-oriented } \\
\text { Culture }\end{array}$ & 4.85 & 1.211 & $.608^{* *}$ & 1 & & & & \\
\hline 3 & $\begin{array}{l}\text { Compete-oriented } \\
\text { Culture }\end{array}$ & 5.31 & 1.181 & $.633^{* *}$ & $.582^{* *}$ & 1 & & & \\
\hline 4 & $\begin{array}{l}\text { Control-oriented } \\
\text { Culture }\end{array}$ & 5.50 & 1.175 & $.688^{* *}$ & $.557^{* *}$ & $.664^{* *}$ & 1 & & \\
\hline 5 & Product Innovation & 5.64 & 1.091 & $.308^{* *}$ & $.414^{* *}$ & $.318^{* *}$ & $.403^{* *}$ & 1 & \\
\hline 6 & $\begin{array}{l}\text { Financial } \\
\text { Performance }\end{array}$ & 5.87 & .928 & $.376^{* *}$ & $.362^{* *}$ & $.333^{* *}$ & $.392^{* *}$ & $.484^{* *}$ & 1 \\
\hline
\end{tabular}

**. Correlation is significant at the 0.01 level (2-tailed).

\subsection{Measurement Model Assessment}

\subsubsection{Reliability Test}

The reliability test of the variables is indicated in table 3 . The internal consistency, indicator reliability, and the convergent reliability of the latent variables were all assessed via the Rho_A, factor loadings, Average Variance Extracted (AVE), and the Composite Reliability (CR). All the variables achieved values above the recommended values (Hulland, 1999; Gefen et al., 2000; Nunnally, 1978; Fornell \& Larcker, 1981; Bagozzi \& Yi, 1988) signifying the reliability of the data. Table 3 shows the details.

Table 3. Measurement Model Assessment 


\begin{tabular}{|c|c|c|c|c|c|c|}
\hline Variable & Items & Loadings $^{\mathbf{a}}$ & $\begin{array}{l}\text { Cronbach's } \\
\text { Alphab }^{\text {blo }}\end{array}$ & rho_A $\mathbf{A}^{\mathrm{b}}$ & $\begin{array}{l}\text { Composite } \\
\text { Reliability } \\
(\mathbf{C R})^{\mathfrak{c}}\end{array}$ & $\begin{array}{l}\text { Average } \\
\text { Variance } \\
\text { Extracted } \\
(\text { AVE) })^{d}\end{array}$ \\
\hline \multicolumn{7}{|l|}{ Collaborate-oriented } \\
\hline \multirow{4}{*}{ Culture } & $\mathrm{CC} 3$ & 0.833 & & & & \\
\hline & $\mathrm{CC} 4$ & 0.842 & & & & \\
\hline & $\mathrm{CC} 5$ & 0.810 & & & & \\
\hline & CC6 & 0.784 & & & & \\
\hline \multicolumn{7}{|l|}{ Innovate-oriented } \\
\hline \multirow{5}{*}{ Culture } & $\mathrm{ADC} 2$ & 0.867 & & & & \\
\hline & ADC 3 & 0.725 & & & & \\
\hline & $\mathrm{ADC} 4$ & 0.804 & & & & \\
\hline & ADC 5 & 0.829 & & & & \\
\hline & ADC 6 & 0.729 & & & & \\
\hline \multicolumn{7}{|l|}{ Compete-oriented } \\
\hline \multirow{5}{*}{ Culture } & $\mathrm{MC} 2$ & 0.778 & & & & \\
\hline & MC3 & 0.672 & & & & \\
\hline & MC4 & 0.747 & & & & \\
\hline & MC5 & 0.789 & & & & \\
\hline & MC6 & 0.776 & & & & \\
\hline \multicolumn{7}{|l|}{ Control-oriented } \\
\hline \multirow{5}{*}{ Culture } & $\mathrm{HC} 2$ & 0.630 & & & & \\
\hline & $\mathrm{HC} 3$ & 0.839 & & & & \\
\hline & $\mathrm{HC} 4$ & 0.865 & & & & \\
\hline & $\mathrm{HC} 5$ & 0.823 & & & & \\
\hline & HC6 & 0.810 & & & & \\
\hline \multirow[t]{3}{*}{ Product Innovation } & PrdtInnov1 & 0.834 & 0.852 & 0.859 & 0.900 & 0.692 \\
\hline & PrdtInnov2 & 0.835 & & & & \\
\hline & PrdtInnov3 & 0.826 & & & & \\
\hline
\end{tabular}




\begin{tabular}{|c|c|c|c|c|c|c|}
\hline & PrdtInnov4 & 0.832 & & & & \\
\hline \multirow[t]{5}{*}{$\begin{array}{l}\text { Financial } \\
\text { Performance }\end{array}$} & FinPer1 & 0.689 & \multirow[t]{5}{*}{0.825} & \multirow[t]{5}{*}{0.838} & \multirow[t]{5}{*}{0.878} & \multirow[t]{5}{*}{0.591} \\
\hline & FinPer2 & 0.814 & & & & \\
\hline & FinPer3 & 0.854 & & & & \\
\hline & FinPer4 & 0.751 & & & & \\
\hline & FinPer5 & 0.723 & & & & \\
\hline
\end{tabular}

Items removed: indicator items with loadings below 0.5: $\mathrm{CC} 1$.

a. All items loadings $>0.5$ indicate Indicator Reliability (Hulland, 1999)

b. All Cronbach's Alphas/rho_A > 0.7 indicate Indicator Reliability ( Nunnaly, 1978)

c. All Composite Reliability (CR) $>0.7$ indicate Internal Consistency (Gefen et al., 2000).

d. All Average Variance Extracted (AVE) $>0.5$ indicate Convergent Reliability (Bagozzi \& Yi, 1988; Fornell \& Larcker, 1981)

\subsubsection{Discriminant Validity Test}

The discriminant validity of the latent constructs was assessed via the Fornell-Larcker criterion and Heterotrait-Monotrait (HTMT) ratio. The diagonals in table 4 are the square root of the average variance extracted (AVE) of the latent variables and are the highest in any row or column which shows a good discriminant validity (Fornell \& Larcker, 1981). As Table 5 shows, HTMTs of the latent variables are all below 1 which signifies a good discriminant validity (Kline, 2011; Gold et al., 2001).

Table 4. Discriminant Validity Test using Fornell-Larcker Criterion

\begin{tabular}{|l|l|l|l|l|l|l|l|}
\hline & Variable & $\mathbf{1}$ & $\mathbf{2}$ & $\mathbf{3}$ & $\mathbf{4}$ & $\mathbf{5}$ & $\mathbf{6}$ \\
\hline $\mathbf{1}$ & $\begin{array}{l}\text { Innovate-oriented } \\
\text { Culture }\end{array}$ & $\mathbf{0 . 7 8 5}$ & & & & & \\
\hline $\mathbf{2}$ & $\begin{array}{l}\text { Collaborate-oriented } \\
\text { Culture }\end{array}$ & 0.723 & $\mathbf{0 . 7 2 8}$ & & & & \\
\hline $\mathbf{3}$ & $\begin{array}{l}\text { Financial } \\
\text { Performance }\end{array}$ & 0.562 & 0.551 & $\mathbf{0 . 7 6 9}$ & & & \\
\hline $\mathbf{4}$ & $\begin{array}{l}\text { Control-oriented } \\
\text { Culture }\end{array}$ & 0.703 & 0.704 & 0.511 & $\mathbf{0 . 7 9 3}$ & & \\
\hline $\mathbf{5}$ & $\begin{array}{l}\text { Compete-oriented } \\
\text { Culture }\end{array}$ & 0.563 & 0.663 & 0.487 & 0.626 & $\mathbf{0 . 7 4 9}$ & \\
\hline $\mathbf{6}$ & Product Innovation & 0.545 & 0.512 & 0.603 & 0.493 & 0.528 & $\mathbf{0 . 8 3 2}$ \\
\hline
\end{tabular}

Footnote. The diagonals are the square root of the AVE of the latent variables and are the highest in any column or row indicating discriminant validity (Fornell \& Larcker, 1981). 
Table 5. Discriminant Validity Test using Heterotrait-Monotrait (HTMT) Ratio

\begin{tabular}{|l|l|l|l|l|l|l|l|}
\hline & Variable & $\mathbf{1}$ & $\mathbf{2}$ & $\mathbf{3}$ & $\mathbf{4}$ & $\mathbf{5}$ & $\mathbf{6}$ \\
\hline $\mathbf{1}$ & $\begin{array}{l}\text { Innovate-oriented } \\
\text { Culture }\end{array}$ & & & & & & \\
\hline $\mathbf{2}$ & $\begin{array}{l}\text { Collaborate-oriented } \\
\text { Culture }\end{array}$ & 0.663 & & & & & \\
\hline $\mathbf{3}$ & $\begin{array}{l}\text { Financial } \\
\text { Performance }\end{array}$ & 0.660 & 0.663 & & & & \\
\hline $\mathbf{4}$ & $\begin{array}{l}\text { Control-oriented } \\
\text { Culture }\end{array}$ & 0.699 & 0.704 & 0.598 & & & \\
\hline $\mathbf{5}$ & $\begin{array}{l}\text { Compete-oriented } \\
\text { Culture }\end{array}$ & 0.649 & 0.685 & 0.587 & 0.616 & & \\
\hline $\mathbf{6}$ & Product Innovation & 0.615 & 0.577 & 0.703 & 0.544 & 0.613 & \\
\hline
\end{tabular}

The latent variables have low correlation with each other and that shows good discriminant validity (Kline, 2011; Gold et al., 2001).

\subsubsection{Common Method Bias Test}

Taking into account the use of questionnaires to obtain the data for both the predictor and criterion variables in this study, the researchers investigated potential method bias in the data, such as social desirability, common ratter effect, consistency motif, mood state, and common scale anchors (Podsakoff et al., 2003). Kock's (2015) guidelines for assessing common method bias in PLS-SEM were used to determine if a method bias is affecting the measurement model. According to Kock (2015), the occurrence of a VIF greater than 3.3 is an indication that a model may be contaminated by common method bias. Therefore, if all variance inflation factors (VIFs) resulting from a full collinearity test are equal to or lower than 3.3, the model can be considered free of common method bias. As table 6 shows, the test shows that the model is free from the influence of common method bias.

Table 6. Common Method Bias Test

\begin{tabular}{|c|c|c|c|}
\hline & \multicolumn{3}{|c|}{ Full Collinearity VIF Values } \\
\hline a. & \multicolumn{3}{|c|}{ Connecting all the variables to Financial Performance } \\
\hline & \multirow[b]{2}{*}{ Financial Performance } & Organizational Culture & Innovation \\
\hline & & 2.728 & 2.413 \\
\hline b. & \multicolumn{3}{|c|}{ Connecting all the variables to Organizational Culture } \\
\hline & & Financial Performance & Innovation \\
\hline
\end{tabular}




\begin{tabular}{|l|l|l|}
\hline \multicolumn{4}{|l|}{ Organizational Culture } & 3.112 & 2.827 \\
\hline \multicolumn{3}{|l|}{} \\
\hline c. $\quad$ Connecting all the variables to Innovation \\
\hline \multirow{3}{*}{ Innovation } & Organizational Culture & Financial Performance \\
\cline { 2 - 3 } & 1.934 & 1.983 \\
\hline
\end{tabular}

VIFs lower than 3.3 shows that the model is free from common method bias Kock (2015)

\subsection{Assessment of Dominant Type of Organizational Culture within RCBs in Ghana}

We used descriptive statistics to determine the dominant organizational culture prevailing within RCBs in Ghana. From table 7, the results show that the predominant organizational culture within RCBs in Ghana is a control-oriented (hierarchy) culture with a mean value of 5.50, while innovate-oriented culture (adhocracy) with a mean value of 4.85 is identified by the staff of RCBs as the least organizational culture in their operations. This empirical finding supports our first hypothesis, H1, which is, therefore, confirmed.

Table 7. Descriptive Statistics of Dominant Organizational Cultures of the Banks

\begin{tabular}{|l|l|l|l|l|l|l|}
\hline $\begin{array}{l}\text { Type of Org. } \\
\text { Culture }\end{array}$ & N & Range & Minimum & Maximum & Mean & $\begin{array}{l}\text { Std. } \\
\text { Deviation }\end{array}$ \\
\hline $\begin{array}{l}\text { Control-oriented } \\
\text { Culture }\end{array}$ & 92 & 5 & 2 & 7 & $\mathbf{5 . 5 0}$ & 1.175 \\
\hline $\begin{array}{l}\text { Compete-oriented } \\
\text { Culture }\end{array}$ & 92 & 5 & 2 & 7 & $\mathbf{5 . 3 1}$ & 1.181 \\
\hline $\begin{array}{l}\text { Collaborate-oriented } \\
\text { Culture }\end{array}$ & 92 & 5 & 2 & 7 & $\mathbf{5 . 2 4}$ & 1.116 \\
\hline $\begin{array}{l}\text { Innovate-oriented } \\
\text { Culture }\end{array}$ & 92 & 5 & 2 & 7 & $\mathbf{4 . 8 5}$ & 1.211 \\
\hline Valid N (listwise) & 92 & & & & & \\
\hline
\end{tabular}

Source: Field Study

\subsection{Structural Model}

The relationships between the types of organizational culture, product innovation, and financial performance were assessed via the bootstrapping procedure of Smart PLS. Figure 3 shows the bootstrapping direct effect results ( $\mathrm{t}$-values and values above 1.96 show significance). 


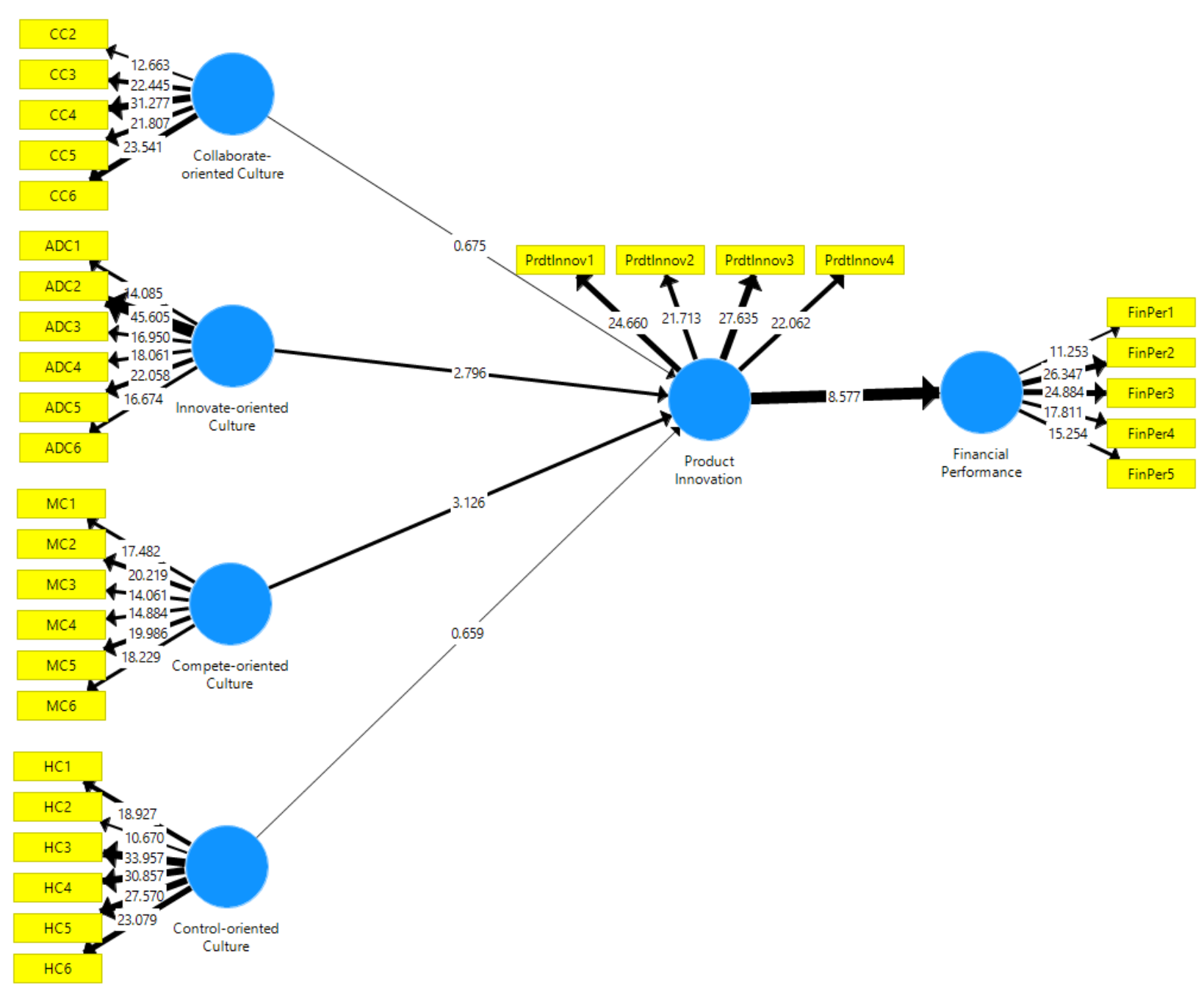

Figure 3. Bootstrapping Direct Effect Results (T-values)

4.4.1 Structural Model Hypotheses Testing: Bootstrapping Direct Effects Results (path coefficients)

Table 8 shows the relationship between the various variables. It shows the coefficients in the structural model and the associated $p$-values and their corresponding effect sizes $\left(\mathrm{f}^{2}\right)$.

Table 8. Bootstrapping Direct Effects Results (Path Coefficients)

\begin{tabular}{|l|l|l|l|l|l|l|l|l|}
\hline Hypotheses & Relationships & Std.Beta & Std.Error & P-values & Decision & $\begin{array}{l}\text { Effect } \\
\text { Size } \\
\left.\mathbf{f}^{2}\right)\end{array}$ & 5\%CI LL & 95\%CI UL \\
\hline & $\begin{array}{l}\text { Collaborate-oriented } \\
\text { Culture } \\
\text {->Product } \\
\text { Innovation }\end{array}$ & 0.066 & 0.101 & 0.488 & Not Supported & 0.003 & -0.098 & 0.236 \\
\hline
\end{tabular}




\begin{tabular}{|l|l|l|l|l|l|l|l|l|}
\hline H3 & $\begin{array}{l}\text { Innovate-oriented } \\
\text { Culture } \\
->\text { Product } \\
\text { Innovation }\end{array}$ & 0.296 & 0.107 & 0.006 & Supported & 0.055 & 0.116 & 0.462 \\
\hline H4 & $\begin{array}{l}\text { Compete-oriented } \\
\text { Culture } \\
->\text { Product } \\
\text { Innovation }\end{array}$ & 0.276 & 0.082 & 0.001 & Supported & 0.062 & 0.150 & 0.412 \\
\hline H5 & $\begin{array}{l}\text { Control-oriented } \\
\text { Culture -> Product } \\
\text { Innovation }\end{array}$ & -0.070 & 0.100 & 0.520 & Not Supported & 0.003 & -0.094 & 0.239 \\
\hline \hline H6 & $\begin{array}{l}\text { Product Innovation } \\
-> \\
\text { Performance }\end{array}$ & 0.605 & 0.071 & 0.000 & Supported & 0.571 & 0.485 & 0.715 \\
\hline
\end{tabular}

As Table 8 shows, collaborate-oriented culture recorded a positive but statistically insignificant effect on product innovation $(\beta=0.066 ; p>0.05)$. Innovate-oriented culture positively and significantly affected product innovation $(\beta=0.296 ; \mathrm{p}<0.01)$. Likewise compete-oriented culture $(\beta=0.276 ; p<0.01)$. Control-oriented culture recorded a negative but statistically insignificant effect on product innovation $(\beta=-0.070 ; p>0.05)$. Product innovation recorded a strong significant positive effect on financial performance $(\beta=0.605$; $\mathrm{p}<0.01)$.

P-values show the significance of the relationship while effect size $\left(\mathrm{f}^{2}\right)$ shows the size of an effect. Based on Cohen's (1988) guidelines on effect size $(>0.35=$ large; $<0.15=$ medium; $<0.02=$ small), both collaborate-oriented and control-oriented cultures had a small effect size, while innovate-oriented and collaborate-oriented cultures had a medium effect size. Product innovation, however, had a large effect size on financial performance. The results, therefore, support hypotheses H3, H4, and H6 while hypotheses $\mathrm{H} 2$ and $\mathrm{H} 5$ are not supported.

\section{Discussion}

Many scholars have recognized organizational culture as an influential tool in managerial actions and decision-making. In this paper, we explore the dominant organizational culture prevailing within the RCBs in Ghana and how each of the identified cultures influences product innovation towards the banks' financial performance.

First, our empirical finding reveals that control-oriented culture is the dominant organizational culture in the rural banking set-ups in Ghana. This is followed by compete-oriented culture with innovate-oriented being the least exhibited culture among the banks. The results contradict the findings of Mariama-Zakari and Owusu-Ansah (2013) who found market (compete-oriented) culture as the dominant culture in the Ghanaian banking institutions. The inconclusive results may be attributed to the difference in the focus of both studies. In our research, the focus is on rural community banks (RCBs) while 
Mariama-Zakari and Owusu-Ansah (2013) focused on a few universal banks. From the empirical findings, the dominant control-oriented culture demonstrates that RCBs have a duty of care to their depositors' funds and therefore need necessary control mechanisms and risk management policies in place to ensure smooth and efficient operation. Such cultural orientation aimed at ensuring risk-minimization is very crucial in the banking setup. However, much control stifles creative thinking of employees thereby affecting the bank's efforts to introduce innovative financial products capable of attracting and meeting customers' needs. In that case, innovativeness suffers in the interest of safety and prudence. This calls for striking a perfect balance between ensuring strict adherence to rules and procedures, and freedom to experiment with innovative ideas so that the needed benefits can be realized.

Second, with regards to the relationship between the organizational culture types and product innovation, the results show that:

(i) Innovate-oriented culture can facilitate product innovation among RCBs. Banks with a higher level of innovate-oriented culture gives room for experimentation of new products/services while the management style encourages freedom of thought and creative thinking (thinking outside the box) among staff. Also, such cultural orientation constantly monitors the market signals which enable it to identify market trends, potential threats, and opportunities and due to its flexible nature, it can respond appropriately taking advantage of the opportunities while minimizing the risks. Our finding agrees with that of Naranjo-Valencia et al. $(2011,2016)$ and Ogbeibu et al. (2018).

(ii) Compete-oriented culture can support RCBs to introduce new products and services. A commercial entity with this cultural orientation tends to adhere to corporate competitiveness and constant monitoring of the activities of competitors. The activities of competitors serve as a challenge and propel entities with this cultural orientation to adopt innovative practices. Also, customer satisfaction permeates through all its operations, and interactions with its customers and competitors are highly regarded. This network of stakeholders serves as a platform for feedback and exchange of ideas which eventually result in the development of innovative products. This our finding agrees with that of Zhou et al. (2005).

(iii) Collaborate-oriented culture has no significant effect on product innovation. As a cultural orientation that values teamwork, consensus and cooperative processes, and employee development, its effects on product innovation should have been prominent. However, this is not the case. We attribute the situation to too much focus on the human capital within the organization (employee development and retention, team, and leadership development) without a corresponding awareness and responsiveness to the current needs of customers and the activities of competitors. Our finding agrees with Ogbeibu et al. (2018) and Naranjo-Valencia et al. (2016).

(iv) Control-oriented culture recorded a negative beta coefficient against product innovation, though statistically insignificant. The result is consistent with the empirical findings of Ogbeibu et al. (2018). Control-oriented culture thwarts employees' ability to think outside the box towards product innovation to meet market current demands of the business environment.

Third, our study reveals a strong link between product innovation and financial performance. 
This is in line with the findings of previous studies (Asaah et al., 2019; Susman and Min, 2006; Woodcock et al., 2000). It discloses that the more a commercial entity can introduce new products and services into the market, the better its financial performance is likely to be.

This paper provides a significant contribution to literature and managerial implications for managers of RCBs in Ghana. On the theoretical front, few empirical studies have been carried out using the competing values framework to examine the organizational culture of RCBs and its effects on product innovation in the context of a developing economy in Sub-Saharan Africa. This paper has broadened our understanding that organizational cultural orientations that articulate and value customer satisfaction, interaction with customers and competitors can nurture product innovation. The practical implications are that decision-makers of RCBs in Ghana should consider the banks' culture as a major influential factor in their quest to improve their financial performance. It is often overlooked in most activities aimed at turning the financial fortunes for the better meanwhile it has a strong influence on the work attitudes and behavior of members of the organization. Secondly, Ghanaian RCBs should embrace product innovation. The expansion of telecommunications to rural communities and the significant increase in the usage of mobile phones by rural folks offer a great opportunity for RCBs to embrace product innovation via the use of mobile phones. New financial products and services which have been carefully designed and developed to meet the unfilled needs of customers serve as a strong attraction for both existing and potential customers which will eventually result in higher profits. Cultural orientations that will support and facilitate the operations of RCBs to achieving this are innovate-oriented and compete-oriented cultures. Therefore, the decision-makers of Ghanaian RCBs should develop such types of culture. In particular, the RCBs should establish Research and Product Development (RPD) units/departments whose mandate is to develop innovative financial products. This unit should develop innovate-oriented culture as its sub-culture, while the marketing and sales unit, as well as the loan unit, should develop compete-oriented and control-oriented cultures respectively.

\subsection{Conclusion}

Every organization aims to achieve healthy financial performance for growth and survival in this turbulent and competitive market environment. This paper seeks to identify the dominant organizational culture prevailing within RCBs in Ghana and also addresses the relationship between the identified cultures, product innovation, and financial performance. Through purposive sampling, $92 \mathrm{RCBs}$ in Ghana participated in the survey and the data were analyzed using Smart PLS of SEM and SPSS.

The results reveal that RCBs in Ghana exhibit four cultural types namely clan-oriented, control-oriented, innovate-oriented, and market-oriented cultures. However, control-oriented culture is the dominant organizational culture prevailing within the RCBs. Also, the study reveals that product innovation has a strong impact on financial performance, and organizational cultural orientations that facilitate product innovation are innovate-oriented and compete-oriented cultures. It is, therefore, recommended that RCBs in Ghana should establish Research and Product Development (RPD) units with innovate-oriented culture as their sub-culture. 


\subsection{Limitation and Future Research}

In spite of the contributions of the paper, it has some limitations which should be addressed in future studies. The research design is a cross-sectional one which may not adequately reveal the causal association between the variables. Therefore, a longitudinal research design may be considered by future researchers. Also, data from multiple-industrial sectors could be used instead of one as is the case of this paper. The financial performance was self-reported data (questionnaire). Future studies might consider using end-of-year financial statements to deeply establish the relationship between organizational culture, and financial performance.

\section{References}

Adusei, M. (2015). Bank profitability: Insights from the rural banking industry in Ghana, Cogent Economics and Finance., 3(1), 1-15. https://doi.org/10.1080/23322039.2015.1078270 Amabile, T. M. (1998). How to kill creativity, Harvard Business Review, 76, 77-89.

Amabile, T. M. and Pratt, M. G. (2016). The dynamic componential model of creativity and innovation in organizations: Making progress, making meaning, Research in Organizational Behavior, 36, 157-183. https://doi.org/10.1016/j.riob.2016.10.001

Asaah, J. A., Yunfei, S. and Wadei, K. A. (2020). Cultural orientations and product innovation in the Ghanaian banking sector, The Service Industries Journal, 40(7-8), 518-541. doi: 10.1080/02642069.2019.1569635.

Atuahene-Gima, K. and Ko, A. (2001). An empirical investigation of the effect of market orientation and entrepreneurship orientation alignment on product innovation, Organization Science, 12(1), 78-93. https://doi.org/10.1287/orsc.12.1.54.10121

Bagozzi, R. P. and Yi, Y. (1988). On the evaluation of structural equation models, Journal of Academy of Marketing Science, 16(1), 74-94. https://doi.org/10.1007/BF02723327

Bank of Ghana (1995) Restructuring of Rural Banks. The Bank of Ghana, Accra, Ghana.

Bank of Ghana (2017) Banking sector summary vol. 2.1. Accra, Ghana. Available at: https://www.bog.gov.gh/privatecontent/MPC_Press_Releases/Banking Sector Summary January 2017.pdf.

Beamish, P. W., \& Lupton, N. C. (2009). Managing joint ventures, Academy of Management Perspectives, 23(2), 75-94. https://doi.org/10.5465/amp.2009.39985542

Berger, E., \& Nakata, C. (2013). Implementing technologies for financial service innovations in base of the pyramind markets, Product Innovation Management, 30(6), 1199-1211. https://doi.org/10.1111/jpim.12054

Boadi, E. K., Yao, L., \& Lartey, C. V. (2016). Determinants of liquidity of rural and community banks in Ghana, British Journal of Economics, Management and Trade., 12(3), 1-15. https://doi.org/10.9734/BJEMT/2016/24121

Boor, V. der. P., Oliveira, P., \& Veloso, F. (2014). Users as innovators in developing countries: The global sources of innovation and diffusion in mobile banking services, Research Policy, 43, 1594-1607. https://doi.org/10.1016/j.respol.2014.05.003

Boyer, K. K., Leong, G., Ward, P. T., \& Krajewski, L. (1997) .Unlocking the potential of advanced manufacturing technologies, Journal of Operations Management, 15(4), 331-347. https://doi.org/10.1016/S0272-6963(97)00009-0 
Brettel, M., Chomik, C., \& Flatten, T. (2015). How organizational culture influences innovativeness, proactiveness, and risk-taking: Fostering entrepreneurial orientation in SMEs, Journal of Small Business Management, 53(4), 868-885. https://doi.org/10.1111/jsbm.12108

Buschgens, T., Bausch, A., \& Balkin, D. (2013). Organizational culture and innovation: A meta-analytic review. Journal of Product Innovation Management, 30(4), 763-781. https://doi.org/10.1111/jpim.12021

Cameron, K. and Quinn, R. (1999). Diagnosing and Changing Organizational Culture: Based on the Competing Values Framework. MA: John Wiley \& Sons.

Cameron, K. S. (2006). Competing values leadership: Creating value in organizations. Northampton, MA: Elgar. https://doi.org/10.4337/9781847201560

Cameron, K. S., \& Quinn, R. E. (2006) Diagnosing and Changing Organizational Culture: Based on the Competing Values Framework, revised ed.. Reading, MA: Addison-Wesley.

Casta neda, D. (2015). Knowledge sharing: The role of psychological variables in leaders and collaborators, Suma Psicologica, 22(1), 63-69.

Castellini, M., \& Agyemang, S. (2012). Ownership and board structures to ensuring effective corporate governance through ownership and board control systems, Corporate Ownership and Control, 9(2), 336-343. https://doi.org/10.22495/cocv9i2c3art4

Chang, S. C., \& Lee, M. S. (2007). The effects of organizational culture and knowledge management mechanisms on organizational innovation: An emperical study inTawian, The Business Review, 7(1), 295-301.

Choi, T. Y., \& Eboch, K. (1998). The TQM paradox: Relations among TQM practices, plant performance and customer satisfaction, Journal of Operations Management, 17(1), 59-75. https://doi.org/10.1016/S0272-6963(98)00031-X

Christensen, C. M., \& Bower, J. L. (1996). Customer power, strategic investment, and the failure of leading firms, Strategic Management Journal, 17, 197-218. https://doi.org/ 10.1002/(SICI)1097-0266(199603)17:3\%3C197::AID-SMJ804\%3E3.0.CO;2-U

Cohen, J. (1988). Statistical Power Analysis for the Behavior Sciences. 2nd edn. Hillsdale, NJ: Lawrence Erbaum Associates Inc.

Collier, P. A., Cooke, T. E., \& Glynn, J. J. (1989). Financial and treasury management. Oxford: Heinemann Professional Publishing.

Dadzie, C. A., Winston, E. M., \& Dadzie, K. Q. (2012). Organizational culture, competitive strategy, and performance in Ghana, Journal of African Business, 13(3), 172-182. https://doi.org/10.1080/15228916.2012.727737

Dasmani, L. (2016). Ghana: Mobile phone penetration soars to 128\%, The Africa Report.

Davidson, G. and Coetzee, M. (2007). Organisational culture and financial performance in a South African investment bank, Journal of Industrial Psychology, 33(1), 38-48. https://doi.org/10.4102/sajip.v33i1.261

Day, G. S. (1994). The Capabilities of market-driven organizations. Journal of Marketing, 58, 37-52. https://doi.org/10.1177/002224299405800404

Dayan, M., Zacca, R., Husain, Z., \& Ryan, J. C. (2016). The effect of entrepreneurial orientation, willingness to change, and development culture on new product exploration in 
small enterprises, Journal of Business and Industrial Marketing, 54(9), 2310-2324.

Delis, M. D., Staikouras, P., \& Tsoumas, C. (2015). Enforcement actions and bank behavior. MPRA Working paper. Munich.

Denison, D. R. (1990). Corporate culture and organizational effectiveness. New York,: John Wiley \& Sons.

Denison, D. R., \& Mishra, A. K. (1995). Toward a Theory of Organizational Culture and Effectiveness, Organization Science, 6(2), 204 - 223. https://doi.org/10.1287/orsc.6.2.204

Doyle, M., Chung, A., \& Quigley, P. (2013). Culture in banking: Under the microscope. London, UK.

Fiordelisi, F., Raponi, J., \& Raghavendra-Rau, P. (2015). Corporate culture and enforcement actions in banking.

Fornell, C., \& Larcker, D. F. (1981). Evaluating structural equation models with unobservable variables and measurement error', Journal of Marketing Research, 18(1), 38-50. https://doi.org/10.1177/002224378101800104

Franklin, A., Elena, C., Robert, C., Jun, Q., Lemma, S., \& Patricio, V. (2014). The African financial development and financial inclusion gaps, Journal of African Economies, 23(5), 614-642. https://doi.org/10.1093/jae/eju015

Gefen, D., Straub, D. W., \& Baudraau, M. C. (2000). Structural equation modelingand regression: Guildelines for research practice, Communications of Associations for Information Systems, 4, 1-79. https://doi.org/10.17705/1CAIS.00407

Gilson, L. L., Mathieu, J. E., Shalley, C. E., \& Ruddy, T. M. (2005). Creativity and standardization: Complementary or conflicting drivers of team effectiveness?, Academy of Management Journal, 48, 521-531. https://doi.org/10.5465/amj.2005.17407916

Godfred, A. (2013). Ownership structure, corporate governance and bank efficiency: An empirical analysis of panel data from the banking industry in Ghana, Corporate Governance: The International Journal of Business in Society, 13(3), 274-287. https://doi.org/10.1108/CG-05-2010-0041

Godfred, A. B. (2015). Bank governance, regulation and risk-taking in Ghana. Journal of African Business, 17(1), 1-17. https://doi.org/10.1080/15228916.2016.1106851

Goffee, R., \& Jones, G. (1998). The Character of a Corporation: How Your Company's Culture Can Make or Break Your Business. London: Harper Business.

Gold, A. H., Malhouse, A., \& Segars, A. H. (2001). Knowledge management: An organizational capabilities perspective, Journal of Management Information System, 18(1), 185-214. https://doi.org/10.1080/07421222.2001.11045669

Gumusluoglu, L., \& Ilsev, A. (2009). Transformational leadership, creativity, and organizational innovation, Journal of Business Research, 62, 461-473. https://doi.org/10. 1016/j.jbusres.2007.07.032

Harrison, R. (1972). Understanding your organization's character. Harvard Business Review, $5,119-128$.

Hartnell, C. A., Amy, Y. O., \& Angelo, K. (2011). Organizational culture and organizational effectiveness: A meta-analytic investigation of the competing values framework's theoretical 
suppositions, Journal of Applied Psychology, 96, 677-694. https://doi.org/10.1037/a0023086 Hemmelgarn, A., Glisson, C., \& James, L. (2006). Organizational culture and climate: implications for services and interventions research, Clinical Psychology: Science and Practice, 13(1), 73-89. https://doi.org/10.1111/j.1468-2850.2006.00008.x

Henri, J. (2006). Management control systems and strategy: a resource-based perspective, Accounting, Organizations and Society., 31(6), 529-558. https://doi.org/10.1016/j.aos. 2005.07.001

Hofstede, G., \& Hofstede, G. (2005). Cultures and Organizations: Software of the Mind. New York, NY.: McGraw-Hill.

Hulland, J. (1999) . Partial least squares (PLS) in strategic management research: A review of four recent studies, Strategic Management Journal, 20, 195-204. https://doi.org/10. 1002/(SICI)1097-0266(199902)20:2\%3C195::AID-SMJ13\%3E3.0.CO;2-7

Hult, G. T. M., Ketchen, D. J., Griffith, D. A., Chabowski, B. R., Hamman, M. K., Dykes, B. J., .. Cavusgil, S. T. (2008). An assessment of the measurement of performance in international business research, Journal of International Business Studies, 39(6), 1064-1080. https://doi.org/10.1057/palgrave.jibs.8400398

Hurley, R. (1995) .Group culture and its effect on innovative productivity. Journal of Engineering and Technology Management, 12(1-2), 57-75. https://doi.org/10.1016/0923 $-4748(95) 00004-6$

IFAD (2008) .The Republic of Ghana Rural and Agricultural Finance Program (RAFIP). Rome.

Igo, T., \& Skitmore, M. (2006). Diagnosing the organizational culture of an Australian engineering consultancy using the competing values framework, Construction Innovation, 6(2), 121-139. https://doi.org/10.1108/14714170610710659

Im, G., \& Rai, A. (2008). Knowledge sharing ambidexterity in long-term interorganizational relationshiops, Management Science, 54(7), 1281-1296. https://doi.org/10.1287/mnsc. 1080.0902

Ito, S., Fujimura, S., \& Tamiya, T. (2012). Does cultural assimilation affect organizational decision-making on quality-related incidents? - A company's post-M\&A experience, Journal of International Management, 18(2), 160-179. https://doi.org/10.1016/j.intman.2012.02.004

Jamrog, K., Vickers, M., \& Bear, D. (2006). Building and sustaining a culture that supports innovation. Human Resource Planning, 29(3), 9-19.

Jarnagin, C., \& Slocum, J. W. (2007). Creating corporate cultures through mythopoetic leadership, Organizational Dynamics, 36, 288-302. https://doi.org/10.1016/j.orgdyn.2007.04. 004

Jaskyte, K., \& Dressler, W. (2005). Organizational culture and innovation in nonprofit human service organizations, Administration in Social Work, 29(2), 23-41. https://doi.org/10.1300/ J147v29n02_03

Jaskyte, K., \& Kisieliene, A. (2006). Organizational innovation a comparison of nonprofit human-service organizations in Lithua-nia and the United States, International Social Work, 49(2), 165-176. https://doi.org/10.1177/0020872806061220 
Kim, J., Lee, K., \& Yu, Y. (2004). Corporate culture and organizational performance, Journal of Managerial Psychology, 19(4), 340-359. https://doi.org/10.1108/0268394041 0537927

Kline, R. B. (2011). Principles and Practices of Structural Equation Modeling. New York (NY): Guildford Press.

Kock, N. (2015). Common method bias in PLS-SEM: A full collinearity assessment approach, International Journal of e-Collaboration, 11(4), 1-10. https://doi.org/10.4018/ijec.2 015100101

Laforet, S. (2009). Effects of size, market and strategic orientation on innovation in non-high-tech manufacturing SMEs, European Journal of Marketing, 43(1/2), 188-212. https://doi.org/10.1108/03090560910923292

Laforet, S. (2016). Effects of organisational culture on organisational innovation performance in family firms, Journal of Small Business and Enterprise Development, 23(2), 379-407. https://doi.org/10.1108/JSBED-02-2015-0020

Laforet, S., \& Tann, J. (2006). Innovative characteristics of small manufacturing firms, Journal of Small and Enterprise Development, 13(3), 363-390. https://doi.org/10.1108/ 14626000610680253

Langerak, F. and Hultink, E. (2008). The effect of new product development acceleration approaches on development speed: A case study, Journal of Engineering and Technology Management, 25, 157-167. https://doi.org/10.1016/j.jengtecman.2008.06.004

Lau, C.-M., \& Ngo, H.-Y. (2004). The HR system, organizational culture, and product innovation. International Business Review, 13(6), 685-703. https://doi.org/10.1016/j.ibusrev. 2004.08.001

Leskaj, E., Lipi, I. and Ramaj, R. (2013). Features of organizational culture and their impact on banking system performance, International Journal of Economic Practices and Theories, 3(4), 288-293.

Liao, S. (2015). Comparison of competing models and multi-group analysis of organizational culture, knowledge transfer, and innovation capability, Knowledge Management Research and Practice, 13(3), 248-260. https://doi.org/10.1057/kmrp.2013.46

Lin, C. Y., \& Chen, M. Y. (2007). Does innovation lead to performance? An empirical study of SMEs in Taiwan, Management Research News, 30(2), 115-132. https://doi.org/10.1108/ 01409170710722955

Littler, D., \& Melanthiou, D. (2006). Consumer perceptions of risk and uncertainty and the implications for behaviour towards innovative retail services: The case of internet banking, Journal of Retailing and Consumer Services, 13(6), 431-443. https://doi.org/10.1016/ j.jretconser.2006.02.006

Llorens, R., Ruiz, A., \& Garcia, V. (2015). Influence of support leadership and teamwork cohesion on organizational learning, innovation and performance: An empericial examination. Technovation, 25, 1159-1172. https://doi.org/10.1016/j.technovation.2004.05.002

Lundy, A., \& Cowling, A. (1996). Strategic Human Resource Management. London: Routledge. 
Lyons, K. R., Chatman, A. J., \& Joyce, K. C. (2007). Innovation in service: Corporate culture and investment banking, California Management Review, 50(1), 174-191. https://doi.org/ $10.2307 / 41166422$

Marcella, B. (2010). Organizational culture in financial organizations: Time for change, OACI online.

Mariama-Zakari, P. K., \& Owusu-Ansah, W. (2013). Organizational culture and organisational performance: Empirical evidence from the banking industry in Ghana, International Journal of Business, Humanities and Technology, 3(1), 95-107.

Martin, J. (1992) Cultures in organizations: Three perspectives. New York: Oxford University Press.

Martins, E. C., \& Terblanche, F. (2003). Building organizational culture that stimulates creativity and innovation. European Journal of Innovation Management, 6(1), 6-74. https://doi.org/10.1108/14601060310456337

Marx, J., De Swart, C., \& Nortjé, A. (1999). Financial management in Southern Africa. Cape Town: Pearson Education South Africa.

Mclean, L. (2005). Organizational culture's influence on creativity and innovation: A review of the literature and implications for human resource development, Advances in Developing Human Resources, 7(2), 226-246. https://doi.org/10.1177/1523422305274528

Mehta, S., \& Sharma, N. (2016). Job involvement and organizational culture in Banks: An empirical study, International Journal of Innovative Research and Practices, 4(3), 16-32.

Mwashighadi, G. K., \& Kising'u, T. M. (2017). Role of organizational culture on organizational performance of commercial banks in Kenya: A case of commercial banks in Voi sub county, The Strategic Journal of Business and Change Management, 4(14), 241-262.

Naidoo, V. (2010). Firm survival through a crisis: The influence of market orientation, marketing innovation and business strategy. Industrial Marketing Management, 39, 13111320. https://doi.org/10.1016/j.indmarman.2010.02.005

Nair, A., \& Fissha, A. (2010). Rural banking: The case of rural and community banks in Ghana. World Bank Agriculture and Rural Development. https://doi.org/10.1596/27725

Naranjo-Valencia, J., Jiménez-Jiménez, D. and Sanz-Valle, R. (2010).Organizational culture as determinant of product innovation, European Journal of Innovation Management, 13(4), 466-480. https://doi.org/10.1108/14601061011086294

Naranjo-Valencia, J., Jiménez-Jiménez, D., \& Sanz-Valle, R. (2016). Studying the links between organizational culture, innovation, and performance in Spanish companies, Revista Latinoamericana de Psicología., 48(1), 30-41. https://doi.org/10.1016/j.rlp.2015.09.009

Nooteboom, B. (1994). Innovation and diffusion in small firms: theory and evidence, Small Business Economics, 66(5), 327-347. https://doi.org/10.1007/BF01065137

Nunnally, J. C. (1978). Psychometric Theory. 2nd edn. New York (NY): McGraw-Hill.

Nyarko, F. K., Kong, Y., \& Naiping, Z. (2017). Corporate governance and performance of firms: An empirical evidence from the banking sector of Ghana, Journal of Economics and International Business Management, 5(1), 14-29.

Obenchain, A., \& Johnson, W. (2004). Product and process innovation in service 
organizations: the influence of organizational culture in higher education institutions, Journal of Applied Management and Entrepreneurship, 9(3), 91-113.

OECD Oslo Manual (2005). Guidelines for collecting and interpreting technological innovation data, 3rd Edition,. Paris.

Ogbeibu, S., Abdelhak, S., \& Gaskin, J. (2018). The moderating effect of benevolence on the impact of organisational culture on employee creativity, Journal of Business Research, 90, 334-346. https://doi.org/10.1016/j.jbusres.2018.05.032

Ogbonna, E. and Harris, L.(2000). Leadership style, organizational culture and performance: empirical evidence of UK companies. International Journal of Human Resource Management, 11(4), 766-788. https://doi.org/10.1080/09585190050075114

Podsakoff, P. M., MacKenzie, S. B., Lee, J.-Y., \& Podsakoff, N. P. (2003). Common method biases in behavioral research: A critical review of the literature and recommended remedies, Journal of Applied Psychology, 88(5), 879-903. https://doi.org/10.1037/0021-9010.88.5.879

Poskiene, A. (2006). Organizational Culture and Innovations', Engineering Economics, 46(1), 45-50.

PricewaterhouseCoopers (Ghana) (2010). Risk management in well capitalized banks, the 2010 Ghana banking survey. Accra, Ghana.

Quinn, R., \& Spreitfzer, G. (1991). The psychometrics of the competing values culture instrument and analysis of the impact of organizational culture on quality of life, in Woodman, R. and Padmore, W. (Eds)[M], Research in Organizational Change and Development. Greenwich,CT: JAI Press.

Rogers, E. M. (2003). Diffusion of innovations. 5th ed. New York: Free Press.

Rohlfer, Y., \& Zhang, Y. (2016). Cultural studies in international busines: Paradigmatic shifts, European Business Review, 28(1), 39-62. https://doi.org/10.1108/EBR-07-2015-0070

Ruvio, A., Shoham, A., Vigoda-Gadot, E., \& Schwabsky, N. (2014). Organizational innovativeness: Construct development and cross-cultural validation, Journal of Product Innovation Management, 31(5), 1004-1022. https://doi.org/10.1111/jpim.12141

Saeidi, S. P., Othman, M. S. H., Saeidi, P., \& Saeidi, S. P. (2018). The moderating role of environmental management accounting between environmental innovation and firm financial performance, International Journal of Business Performance Management, 19(3), 326-348. https://doi.org/10.1504/IJBPM.2018.10011849

Salavou, H., \& Avlonitis, G. (2008). Product innovativeness and performance: A focus on SMEs, Management Decision, 46(7), 969-985. https://doi.org/10.1108/00251740810890168

Salavou, H., Baltas, G., \& Lioukas, S. (2004). Organizational innovation in SMEs: The importance of strategic orientation and competitive structure, European Journal of Marketing, 38(9), 1091-1112. https://doi.org/10.1108/03090560410548889

Schein, E. H. (1985). Organizational Culture and Leadership. San Francisco: Jossey-Bass.

Schneider, B., Ehrhart, M. G., \& Macey, W. H. (2013). Organizational climate and culture, Annual Review of Psychology, 64, 361-388. https://doi.org/10.1146/annurev-psych113011-143809

Sharma, A., \& Lacey, N. (2004). Linking product development outcomes to market valuation 
of the firm: The case of the US pharmaceutical industry, Journal of Product Innovation Management, 21(5), 297-308. https://doi.org/10.1111/j.0737-6782.2004.00084.x

Sonnenfeld, J. (1988). The Hero's Farewell. New York, NY.: Oxford University Press.

Steel, W. F., \& Andah, D. O. (2004). Rural and Micro Finance Regulation in Ghana: Implications for Development and Performance of Industry, in International Conference on Ghana at the Half of the Century, 18-20.

Steyn, B. L., Warren, B. O., \& Jonker, W. D. (1998). Fundamental aspects of financial management. Pretoria: Renal Publishers.

Stock, G., Mcfaddena, K., \& Gowen, C. (2007).Organizational culture, critical success factors, and the reduction of hospital errors, International Journal Production Economics, 106, 368-392. https://doi.org/10.1016/j.ijpe.2006.07.005

Susman, G., \& Min, A. (2006). Product and service innovation in small and medium sized Enterprises. New York. https://doi.org/10.4337/9781847204431

Tellis, G. J., Prabhu, R., \& Chandy, R. K. (2009). Radical innovation across nations: The preeminence of corporate culture. Journal of Marketing, 73(1), 3-23. https://doi.org/10. 1509/jmkg.73.1.3

Tesluk, P., Faar, J., \& Klein, S. (1997). Influences of organizational culture and climate on individual creativity, The Journal of Creative Behavior, 31(1), 21-44.

Thakor, A. (2016). Corporate culture in banking, Federal Reserve Bank of New York Economic Policy Review,. New York.

Tian, M., Deng, P., Zhang, Y., \& Salmador, M. P. (2018). How does culture influence innovation? A systematic literature review, Management Decision, 56(5), 1088-1107.

Varis, M., \& Littunen, H. (2010). Types of innovation, sources of information and performance in entrepreneurial SMEs, European Journal of Innovation Management, 13(2), 128-154. https://doi.org/10.1108/14601061011040221

Voss, G. B., \& Voss, Z. G. (2000). Strategic orientation and firm performance in an artistic environment, Journal of Marketing, 64(1), 67-83. https://doi.org/10.1509/jmkg.64.1.67.17993

Ward, P. T., \& Duray, R. (2000). Manufacturing strategy in context: Environment competitive strategy and manufacturing strategy, Journal of Operations Management, 18(3), 123-138. https://doi.org/10.1016/S0272-6963(99)00021-2

Woodcock, D., Mosey, P., \& Wood, D. (2000). New product development in British SMEs, European Journal of Businesss Management, 3(4), 212-222. https://doi.org/10.1108/ 14601060010352498

Zhou, J., \& Shalley, C. E. (2008). Handbook of Organizational Creativity. New York, NY.: Taylor \& Francis Group.

Zhou, K. (2006). Innovation, imitation, and new product performance: The case of China, Industrial Marketing Management, 35(3), 394-402. https://doi.org/10.1016/j.indmarman. 2005.10.006

Zhou, K. Z., Yim, C. K., \& Tse, D. K. (2005). The effects of strategic orientations on technology and market-based breakthrough innovations, Journal of Marketing, 69, 42-60. https://doi.org/10.1509/jmkg.69.2.42.60756 


\section{Copyright Disclaimer}

Copyright for this article is retained by the author(s), with first publication rights granted to the journal.

This is an open-access article distributed under the terms and conditions of the Creative Commons Attribution license (http://creativecommons.org/licenses/by/4.0/). 